\title{
Analysis of the Financial Fragility Hypothesis Applied to the Public Sector by Means of Structural Equations
}

\author{
Cláudio Roberto Caríssimo ${ }^{1}$ \\ Postgraduate Programme in Administration (UFLA), Lavras. MG, Brazil \\ Federal University of Alfenas (UNIFAL), Varginha, MG, Brazil \\ claudio.carissimo@unifal-mg.edu.br
}

Eduardo Gomes Carvalho

Federal Center for Technological Education of Minas Gerais (CEFET-MG), Varginha, MG, Brazil

dudugomescarvalho@gmail.com

Francisval de Melo Carvalho

Federal University of Lavras (UFLA), Lavras, MG, Brazil

francarv@ufla.br

Carlos Eduardo Stefaniak Aveline

Federal University of Lavras (UFLA), Lavras, MG, Brazil

carlos.aveline@ufla.br

\begin{abstract}
This study analysed the effects of public debt interest and charges through on Financial Fragility Hypothesis (FFH), in relation to Brazilian states' public debt. Structural equation modelling was used as the empirical procedure. The effects of the structural model's constructs explained 90.2\% of the Public Sector Financial Position. The proposed model showed significance and relevance of the formative indicators. The results show that financial fragility is caused by excessive current spending but is aggravated by interest and amortisation costs that exceed the Current Revenue/Current Expenditure balance. This evidence confirms the assumptions of the FFH when applied to the public sector.
\end{abstract}

Keywords: financial fragility hypothesis, public sector, structural equation modelling

JEL: C14, C39, E12, E60, E62.

\footnotetext{
${ }^{1}$ Responsible for correspondence. Av. Celina Ferreira Ottoni, 4000 - Padre Vitor, Varginha - MG, 37048-395 - Brazil.
} 


\section{Introduction}

The aim of this study is to test the principles of the Financial Fragility Hypothesis (FFH) when applied to the public sector, using structural equations as the empirical procedure. The rationale for this work is that such procedures may reveal relationships among the assumptions of this hypothesis, enriching this field of study in regard to the evaluation of its use in the public finance environment.

Financial instability studies were first undertaken by Hyman Minsky, based on observations between the years 1966 and 1975, characterised by the threat of financial crisis and Federal Reserve interventions (MINSKY, 1977). In this financial environment, economic agents exchange real money for bonds with future maturity, financing production to generate future cash flows, which maintain the debt sustainability (MINSKY, 1977). However, when the future revenue occur and become cash flows for economic units, such flows may not be sufficient to cover production costs and generate surplus resources to cover the financial cost. This Minskyan approach could also be applied to analyse a government's financial fragility. Terra and Ferrari Filho (2020) report the existence of studies on Minsky's financial fragility as applied to the public sector. The work of Ferrari-Filho, Terra and Conceição (2010) should be highlighted, as should their creation of the Financial Fragility Index Applied to the Public Sector, one of the bases of this study.

Following Minsky's reflections (1992, 1977), while one of the reasons for indebtedness in the private sector is the expectation of quasi-rent and leverage for investment and capital assets, in the public sector, the motivation is neither the expectation of future cash flows nor an increase in revenue. According Musgrave (1973), one of the functions of public debt is to create a balance between generations on financing public expenditure and investments. This balance is a result of the use of public goods over time by these generations. Interest, a determining variable in the FFH and inherent to the debt process, is the burden resulting from the cost of capital obtained by borrowing. Interest may contribute to situations of stress or even fragility (Foley, 2003). This situation leads to the following research question: what are the effects of public debt interest and charges on Brazilian states' financial positions? In proposing a response to this question, this study contributes to the literature on financial fragility in the public sector, especially at the subnational level, using the Brazilian states as an empirical base.

In 2014, Brazil plunged into a financial and institutional crisis that caused declines in revenue at the federal, state and municipal levels, in addition to the President's impeachment. The accounts of states such as Minas Gerais, Rio de Janeiro and Rio Grande do Sul were in a situation of fragility. At the same time, there were increases in the base interest rate between 2013 and 2016, with a drop in 2017. This scenario compatible with what Minskyan theory report about interest, economic growth rate and financial fragility.

To test the effects of interest on the public sector's financial fragility, a quantitative approach was adopted using structural equation modelling (SEM) applied to the Brazilian states' accounts from 2013 to 2017. The justification for selecting this period was the use of a five-year time horizon that covered variations in interest and GDP growth rates, continuing through the financial crisis period and reaching the decline in the base interest rate at the beginning of 2017.

This study argues that financial fragility is formed due to excessive current spending but is aggravated by amortisation costs and interest that exceed the Current Revenues/Current Expenditure balance. In other words, the resource deficiency that generates financial fragility 
is linked to insufficient resources, expenditure above revenue collection capacity and excessive interests that affect the distribution and use of public resources.

\section{Theoretical framework}

\subsection{Financial fragility hypothesis}

Financial fragility is described by Minsky as a result of the economic agents' expectations of growth, where they go into debt to be able to leverage production to increase earnings. Thus, according to Foley (2003), financial fragility stems from the widespread practice of companies going into debt to buy capital assets to finance production. This practice is one of the features of capitalist economies with sophisticated capital asset financing operations (MINSKY, 1992).

Minsky $(1977,1986,1992)$ elucidates how companies take on financial liabilities in periods of economic growth, when both lenders and borrowers consider the risk low for both parties. This confidence is due to the economic agents' positive expectations about the future.

Taylor and O'Connell (1985) analysed essays by Minsky on financial instabilities and crises and their relation to macroeconomic aspects, which are determinants of the value of assets resulting from present quasi-rent value, where the realised net value decreases due to falls in this cash flow as a result of a decline in growth rates and an increase in financing interest rates.

In this context, it is observed that studies on financial fragility address not only aspects related to the positions resulting from debt-forming capital structures but also the relationship between the economy's growth rate and the interest rate arising from monetary policy decisions. For Minsky (1977, 1986, 1992), when the expected quasi-rent (i.e., estimated cash flows) is realised, changes occur in financial positions, which he terms hedge, speculative and Ponzi.

According to the concepts presented by Minsky (1992), the hedge position derives from market optimism and the expectation of growth. Within this scenario, investors work in a leveraged manner with the hope that by investing in financial assets and capital, their future returns will be sufficient to cover their financial liability. In this position, economic agents do not need to refinance to settle their financial obligations, i.e., the entry of resources from production covers their costs and financial obligations.

The speculative position represents an imbalance between realised cash flows and financial commitments. In this position, the debtor must refinance part of his financial obligations to honour his commitments (MINSKY, 1992). Such agents have an expected quasi-rent flow that is higher only than the interest commitment, and thus, there is a need to take out financial resources to refinance and be able to honour the principal debt.

Taylor and O'Connell (1985), De Paula and Alves Jr. (2000), Foley (2003) and Gonzalez (2017) highlight the consequences of interest rates to these financial positions when they exceed normal levels. In this dynamic, there are influences of the behaviour of government policies, both in their monetary and financial aspects.

The Ponzi financial position occurs when the realised cash flows are insufficient to cover payment of the principal plus interest or even part of the production costs and maintenance of production activity. In this position, the company may be forced to sell assets to cover its obligations or to take out additional loans to be able to honour its commitments. Furthermore, according to Minsky (1992), in this position, there are negative influences on 
the creditor's safety margin. In this position, the debt begins to grow and tends to become unsustainable in the medium or long term.

These financial positions, along with their mathematical formalisations, in accordance with Foley (2003), are shown in Table 1.

Table 1. Financial positions

\begin{tabular}{l|l}
\hline Hedge & \multicolumn{1}{c}{ Position } \\
Speculative & $r>i>g$ or $r>g>i$ \\
Ponzi & $i>r>i$ \\
\hline
\end{tabular}

Source: The authors, adapted from Foley (2003).

Where:

$r=$ profit rate

$g=$ growth rate

$i=$ interest rate

Analysis of Table 1 reveals the significance of interest in the calculation, including for determining financial fragility, when it becomes greater than the profit rate. This interest will affect the debt service value and can also affect the expected cash flows for the maintenance of production activity. In his general theory, Keynes (1996) expressed caution in regard to the negative effects of interest rates when they are higher than the marginal capital efficiency rate, which represents the rate of return of expected cash flows from capital asset investments.

\subsection{Financial fragility hypothesis applied in the public sector and its index}

In the private sector, economic agents go into debt to purchase capital goods to increase production in anticipation of leveraging their earnings. In the public sector, the motivations or reasons for incurring debt are different. According to Barro (1979) and Musgrave (1973), public debt is incurred due to the generation of government revenue and total spending. Musgrave (1973) expanded the understanding of the causes of public debt, suggesting it to be a resource allocation tool; however, he also cautioned about the problem of debt management and stabilisation of the economy.

By corollary, spending arising from debt includes interest payments, the cost of capital provided by financial agents and/or investors. This financial burden has an effect on budget execution, thus contributing to financial policy restrictions. Such considerations are pertinent to those made by Taylor and O'Connell (1985), Minsky (1992), De Paula and Alves Jr. (2000), Foley (2003) and Gonzalez (2017). In this vein, De Paula and Alves Jr. (2000) advocate the use of Minsky's FFH when analysing a country's economic situation, creating a relationship analogous to that of a large firm. In this regard, an economy or even a government will have greater or lesser financial fragility according to whether the hedge, speculative or Ponzi position predominates.

Even given the considerations and justifications cited within this framework, studies on financial fragility specifically applied to the analysis of governments are not plentiful, despite their importance. Terra and Ferrari Filho (2020) describe studies relating to financial fragility and external policies, non-governmental organisations, interest and tax policy; however, few studies more specifically analyse the financial fragility of governments. Nevertheless, some studies have conducted such analyses, such as that of Argitis and 
Nikolaidi (2014), who calculated financial fragility indices to examine the financial structure of the Greek government ex ante and ex post the sovereign debt crisis in that country in 2009 and, later, in 2016. They concluded that the Greek government's financial austerity actions did not produce substantial results in terms of a decline in financial fragility but rather generated a position that they called ultra-Ponzi.

Picolotto (2016) proposed the Minskyan Government Index (MGI), which measured the variation in the Brazilian state of Rio Grande do Sul's investment index in relation to the variation in its budget outcome. Terra and Ferrari Filho $(2011,2017)$ analysed the financial fragility of the Brazilian government from 2000 to 2009, contributing not only inferences and considerations in regard to the analysed data but also the adaptation of Minsky's financial hypothesis indices for application to the public sector.

To analyse the financial fragility of the Brazilian federal government's public accounts, Terra and Ferrari Filho $(2011,2017)$ adapted the indices and their respective formulas as follows:

First, current and financial income and expenditure are calculated. These accounts are related to those presented in the budget, according to Brazilian fiscal, financial and budgetary legislation:

$R_{f g}=R_{c f g}+R_{f f g}$

where:

$R_{f g}$ represents the sum of current revenues plus financials;

$R_{c f g}$ represents the current revenues;

$R_{f f g}$ represents the financials revenues;

Current and financial expenditure is then determined. Terra and Ferrari-Filho (2017) note that the operation is based on Minsky (1986) and Ferrari-Filho, Terra and Conceição (2010):

$E_{f g}=E_{c f g}+E_{f f g}$

where:

$E_{f g}$ represents the sum of current and financial expenditure; $E_{c f g}$, current expenditures; and

$E_{f f g}$, financial expenditure, and these expenditures are calculated by summing the amortisation costs plus interest. Thus,

$E_{f f g}=A_{f g}+i_{f g}$

where:

$A_{f g}$, represents amortisation costs and

$i_{f g}$, represents interest costs.

Terra and Ferrari Filho (2017) note that when considering the notion of budgetary balance, expenditure must not exceed revenue, leading to the following equation:

$$
R_{c f g}+R_{f f g}=E_{c f g}+E_{f f g}
$$

The financial positions and their respective indices will be calculated as shown in Table 2 . 
Table 2. Financial position indices

\begin{tabular}{|c|c|c|c|}
\hline Calculatec & ndex & & Position \\
\hline$\left(R_{c f g}+R_{f f g}\right)$ & $-E_{c f g}$ & \multirow{2}{*}{$>1$} & \multirow[t]{2}{*}{ Hedge financial position } \\
\hline$A_{f g}+i_{f g}$ & & & \\
\hline$\left(R_{c f g}+R_{f f g}\right)$ & $E_{c f g}$ & \multirow{2}{*}{$>0<1$} & \multirow[t]{2}{*}{ Speculative financial position } \\
\hline$A_{f g}+i_{f g}$ & & & \\
\hline$\left(R_{c f g}+R_{f f g}\right)$ & $-E_{c f g}$ & \multirow{2}{*}{$<0$} & \multirow[t]{2}{*}{ Ponzi financial position } \\
\hline$A_{f g}+i_{f g}$ & & & \\
\hline
\end{tabular}

Source: Adapted from Terra and Ferrari Filho (2017).

The positions in Table 2 represent the Public Sector Financial Fragility Index proposed by Ferrari-Filho, Terra and Conceição (2010). Thus, when indices greater than or equal to 1 are calculated, a hedge financial position is evidenced, expressing the financial sustainability of the analysed government, in which its revenues are sufficient to cover expenditure to maintain government activity plus service the public debt. The index represents a speculative position when it has a calculated value greater than zero and less than one, i.e., it is a positive number indicating that current and financial revenue is able to at least meet current spending and interest. When the calculated index is lower than zero, i.e., negative, current and financial revenue is not sufficient to meet even current spending, thus denoting a Ponzi position.

\subsection{Research structural model}

The structural model used in this study is based on the theoretical contributions of Minsky (1977, 1985, 1992), Taylor and O’Connell (1985), Argitis and Nikolaidi (2016) and, especially, Ferrari-Filho, Terra and Conceição (2010) and Terra and Ferrari Filho (2011, 2017). For this model, the constructs Current Revenues and Investments were considered to be exogenous or independent variables. The constructs Current Expenditure, Interest, Amortisation and Public Sector Financial Position (PSFP) were considered to be endogenous or dependent variables.

The relationship among these constructs, which also represent the structural model's latent variables, is what forms the sets of hypotheses to be tested. The latent variables are constructed by formative effects. The formative effects are constituted by the observed variables, described in Table 3, which shows the constructs and formative variables. For the purposes of this study, the investment variable was considered to have an effect on total spending, i.e., Current Expenditure, thus changing the financial position calculation.

Table 3 shows the constructs and formative variables with the appropriate theoretical basis for their use in this study's proposed structural model.

Table 3. Constructs and formative variables

\begin{tabular}{l|l|l}
\hline Construct & Formative variables & Theoretical basis \\
\hline Current revenue (REC CORR) & Tax revenue & $\begin{array}{l}\text { Taylor and O’Connell (1985); } \\
\text { Minsky (1992); De Paula and }\end{array}$ \\
& Financial revenue & $\begin{array}{l}\text { Alves Jr. (2000); Ferrari-Filho, } \\
\text { Terra and Conceição (2010); }\end{array}$ \\
& Current transfers & \\
\hline
\end{tabular}




\begin{tabular}{|c|c|c|}
\hline & $\begin{array}{l}\text { Current revenue (difference } \\
\text { between total current revenue } \\
\text { less formative revenue, shown } \\
\text { above) }\end{array}$ & $\begin{array}{l}\text { Terra and Ferrari Filho (2011, } \\
\text { 2020); Picolotto (2016) }\end{array}$ \\
\hline $\begin{array}{l}\text { Current expenditure } \quad \text { (DESP } \\
\text { CORR) }\end{array}$ & 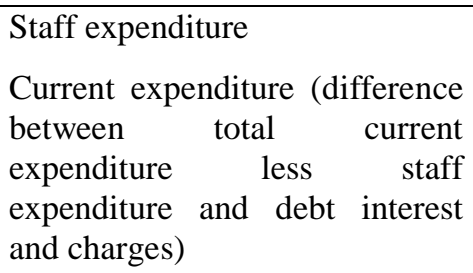 & $\begin{array}{l}\text { Taylor and O’Connell (1985); } \\
\text { Minsky (1992); De Paula and } \\
\text { Alves Jr. (2000); Ferrari-Filho, } \\
\text { Terra and Conceição (2010); } \\
\text { Terra and Ferrari Filho (2011, } \\
\text { 2020); Picolotto (2016) }\end{array}$ \\
\hline Investments (INVEST) & Investments & $\begin{array}{l}\text { Musgrave (1973); Taylor and } \\
\text { O’Connell } \quad(1985) ; \quad \text { Minsky } \\
(1992)\end{array}$ \\
\hline Interest (JUROS) & Interest & $\begin{array}{l}\text { Taylor and O'Connell (1985), } \\
\text { Minsky (1992); De Paula and } \\
\text { Alves Jr. (2000); Foley (2003); } \\
\text { Ferrari-Filho, Terra and } \\
\text { Conceição (2010); Terra and } \\
\text { Ferrari Filho (2011, 2020); } \\
\text { Picolotto (2016) }\end{array}$ \\
\hline Amortisation (AMORTIZ) & Amortisation & $\begin{array}{l}\text { Taylor and O'Connell (1985); } \\
\text { Minsky (1992); De Paula and } \\
\text { Alves Jr. (2000); Foley (2003); } \\
\text { Ferrari-Filho, Terra and } \\
\text { Conceição (2010); Terra and } \\
\text { Ferrari Filho (2011, 2020); } \\
\text { Picolotto (2016) }\end{array}$ \\
\hline $\begin{array}{l}\text { Public Sector Financial Position } \\
\text { (PFSP) }\end{array}$ & $\begin{array}{l}\text { Financial position calculated } \\
\text { according to the financial } \\
\text { fragility hypothesis (FFH) } \\
\text { applied to the public sector }\end{array}$ & $\begin{array}{l}\text { Taylor and O'Connell (1985); } \\
\text { Minsky (1992); De Paula and } \\
\text { Alves Jr. (2000); Foley (2003); } \\
\text { Ferrari-Filho, Terra and } \\
\text { Conceição (2010); Terra and } \\
\text { Ferrari Filho (2011, 2020); } \\
\text { Picolotto (2016) }\end{array}$ \\
\hline
\end{tabular}

Source: The authors.

\subsection{Research hypotheses}

This study seeks to establish the effects of public debt interest and charges on the financial position of Brazilian states. As noted in the introduction, the rationale is that the empirical model confirms the assumptions of the FFH as applied to the public sector to demonstrate the effect of the interest incurred on the financial position of these states. In this regard, eight research hypotheses were formulated that follow the direction of the structural model's paths.

In accordance with the studies of Ferrari-Filho, Terra and Conceição (2010) and Terra and Ferrari Filho $(2011,2017)$, a model was proposed that measures the Public Sector Financial Fragility Index, based on the approach developed by Minsky (1977, 1985, 1992). To calculate this index, Current Revenues are considered to be variables representing resource entries that are expected to finance Current Expenditure, as well as the debt service. Thus, the first hypothesis is presented below.

\section{H1: Current Revenue has a positive effect on the PSFP}


The formulation of the second hypothesis is based on Musgrave (1973), Taylor and O'Connell (1985), as well as Minsky (1992). As part of both their budgetary and distributive functions, governments invest in various types of public works. Therefore, the level of financing to be undertaken to achieve these works is related to Current Revenue as an element guiding the amount to be financed and the ability to pay.

\section{H2: Current Revenue has a positive effect on Investments}

As a result of the theoretical considerations of Minsky's FFH (1977, 1985, 1992), Current Expenditure is used to calculate the PSFP, according to the model proposed by Ferrari-Filho, Terra and Conceição (2010) and Terra and Ferrari Filho (2011, 2017). Thus, the third hypothesis is below.

\section{H3: Current Expenditure has a negative effect on the PSFP}

Given that part of the cash flow is formed by both Current Revenue, as entry, and Current Spending, as exit, the formulation of the next hypothesis is based on Taylor and O'Connell (1985). Such considerations relate to growth rates and financing interest rates, where such phenomena may lead to financial crises and fragility positions. When calculating the PSFP, Current Expenditure applications proposed by Ferrari-Filho, Terra and Conceição (2010) and Terra and Ferrari Filho $(2011,2017)$ should be included. Thus, a fourth hypothesis may be formulated, as shown below.

\section{H4: Current Expenditure has a positive effect on Interest}

According to Barro (1979) and Musgrave (1973), public debt is constituted according to public investments to be made; however, it affects the total amount of government spending. Current Expenditure is included in this total spending. The theoretical considerations of Minsky's FFH $(1977,1985,1992)$ are included, along with the model proposed by Ferrari-Filho, Terra and Conceição (2010) and Terra and Ferrari Filho (2011, 2017).

\section{H5: Investments have a negative effect on Current Expenditure}

Interest and charges affect the amount of amortisation to be carried out. This fact is one of the foundations of the FFH and is a predominant element in establishing the Ponzi financial position, wherein an institution's cash flows are not sufficient to repay the interest and share of public debt. These considerations have been described by Minsky (1977, 1986, 1992) and added to the model applied to the public sector.

\section{H6: Interest has a positive effect on Amortisation}

The seventh hypothesis considers that Amortisation adversely affects the PSFP. This account, plus the effect of interest, are related to an institution's cash flow. According to the model proposed by Ferrari-Filho, Terra and Conceição (2010) and Terra and Ferrari Filho (2011, 2017), Amortisation includes the budgetary accounts used to measure the PSFP.

\section{H7: Amortisation has a negative effect on the PSFP}

Lastly, the eighth hypothesis, similarly to the seventh, considers that Interest adversely affects the PSFP. This account, plus the effect of Amortisation, is related to an institution's cash flow. In the model proposed by Ferrari-Filho, Terra and Conceição (2010) and Terra and Ferrari Filho $(2011,2017)$, debt interest and charges evidenced in the budget are deductible variables when measuring the PSFP and the Public Sector Financial Fragility Index.

\section{H8: Interest has a negative effect on the PSFP}




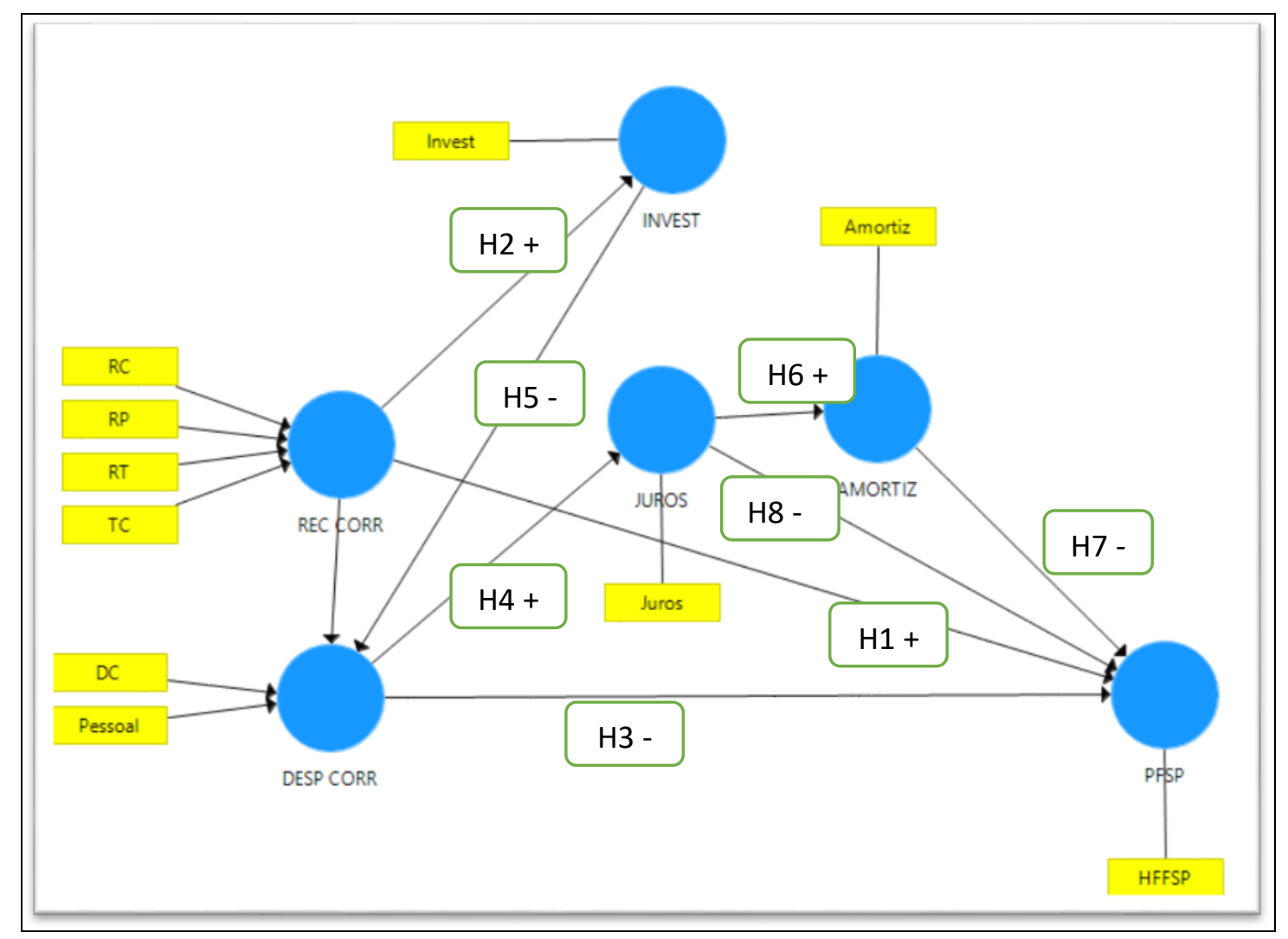

Source: The authors.

Figure 1. Research Structural Model

Figure 1 shows the structural model and the relationship among the constructs. According to the guidelines of Hair et al. (2014), this model is a formative measurement model. A formative measurement model has the following defining characteristics: the indicator/formative variables are the cause of the construct; they are not interchangeable, as in a reflective model; each indicator captures a particular aspect of the construct; and the omission of any indicator can substantially alter the nature of the construct and its amplitude (Hair et al., 2014). It should be noted that $\mathrm{R}^{2}$ will be calculated for the endogenous (dependent) variables in the model. The acronyms used in tables and constructs are: RC (Current Revenue), RP (Financial Revenue), RT (Tax Revenue), TC(Current Trasnfer), DC(Current Expenditures), Pessoal (Staff), Juros (Interest), Invest(Invest), Amortiz (Amortisation).

\section{Methodological procedures}

SEM (structural equation modelling) was used as the empirical procedure to analyse the effect of interest and public debt charges on the Brazilian states' financial positions. SEM is a technique that works with the relationships among sets of dependent variables and more efficiently estimates a simultaneous set of multiple linear regressions (Hair et al., 2005). This technique is based on the partial least squares (PLS) approach, which estimates latent variables as exact linear combinations of the observed measurements, providing the exact definition of the component scores (Anderson and Gerbing, 1988). The structural model produced by SEM works with exogenous (independent) and endogenous (dependent) variables. 
In this study, the SEM technique used was based on the PLS-SEM statistical method, which is non-parametric and based on ordinary least squares (OLS). In the PLS-SEM modeling process, there are constructs that can be both exogenous and endogenous (Hair et al., 2014). Consequently, the statistical properties of the OLS fit to the PLS-SEM (Hair et al., 2014). This technique uses the path weighting scheme, since it calculates a higher $\mathrm{R}^{2}$ value for the endogenous latent variables and can be used in all types of structural models (Hair et al., 2014).

\subsection{Constructs and formative variables}

For the application of the PLS-SEM method, paths are formed by means of constructs that represent latent variables (Hair et al., 2014). The relationships among these latent variables direct the hypotheses to be tested and form the structural model. These latent variables are formed by forming variables. These forming variables can come from primary data, obtained, for example, in interviews, or from secondary data, for example, from other sources such as financial statements and accounting performance reports. In this study, the secondary data representing the formative variables were obtained from budgetary revenue and expenditure statements, available on the website of the National Treasury (Secretaria do Tesouro Nacional - STN), via SICONFI (Sistema de Informações Contábeis e Fiscais do Setor Público Brasileiro - The Brazilian Public Sector Accounting and Financial Information System), available at https://siconfi.tesouro.gov.br/siconfi/index.jsf.

The analysed period was 2013 to 2017 . This period was chosen because it covered variations in interest and GDP growth rates, continuing through the financial crisis period and extending until the decline in the base interest rate starting at the beginning of 2017. Data were deflated using the Getúlio Vargas Foundation's IGP-M index.

The sample comprised 27 Brazilian states. GPower software, developed by Faul et al. (2007), was also used to estimate the sample size. Loading with an effect size of 0.15 and using a 0.05 error probability determination, a sample size of at least 85 observations was calculated. The sample of the 27 states in the five-year period had a total of 135 longitudinal and 10 transverse observations, resulting in a total of 1,350 data in the panel. The software used was SmartPLS®.

\section{Results and discussion}

\subsection{Structural equation modelling}

Figure 2 shows the results of the structural model. The model chosen used the path weighting scheme and a stopping criterion of $10^{\wedge}-7$ with a maximum number of 300 iterations. At this point, the model confirms the theoretical assumptions of the FFH as applied to the public sector, and the set of variables explains $90.2 \%$ of the PSFP. The PSFP is the result of subtracting Current Revenue, net of Current Spending and Debt Service, which is the sum of Interest and Amortisation, as described in theoretical reference section 2.2. The Investments variable is not part of the model to calculate the PSFP and therefore the Public Sector Financial Fragility Index, but it was incorporated in the model because it can affect total Current Expenditure. This estimate was confirmed by its producing, together with the effect of Current Revenue, an $\mathrm{R}^{2}$ of $99.0 \%$. The Current Expenditure variable explains $89.2 \%$ of Interest. In turn, note the relevance of the effect of the Interest variable in relation both to the amount of Amortisation and to the PSFP. Thus, in general, all chosen latent variables 
explain $90.2 \%$ of the PSFP, and by corollary, in this work, explain the Brazilian states' financial positions.

The Interest variable had a positive effect on Amortisation, as corroborated by the predictor of 0.912; and Amortisation had a negative effect on PSFP, where the predictor is 0.399. In turn, Current Expenditure has a predictor of -5.123. These data explain the significance of Interest and Amortisation on the states' financial positions and the predominance of spending with Current Expenditure, with staff spending - 0.395 - being relevant both in costing and in terms of affecting the PSFP. Such evidence validates hypotheses $\mathrm{H} 1-\mathrm{H} 7$ formulated for this work, but does not uphold $\mathrm{H} 8$.

This exception in validating hypothesis H8 - Interest has a negative effect on the Public Sector's Financial Position - occurs because the predictor has a positive effect on the latent variable PSFP. However, this positive effect may be because the Public Sector's Financial Positions for this sample and in this period of time, on average, have negative results. Thus, a negative effect on a negative result generates a positive effect, since a negative variable added to an equally negative position increases the negative result.

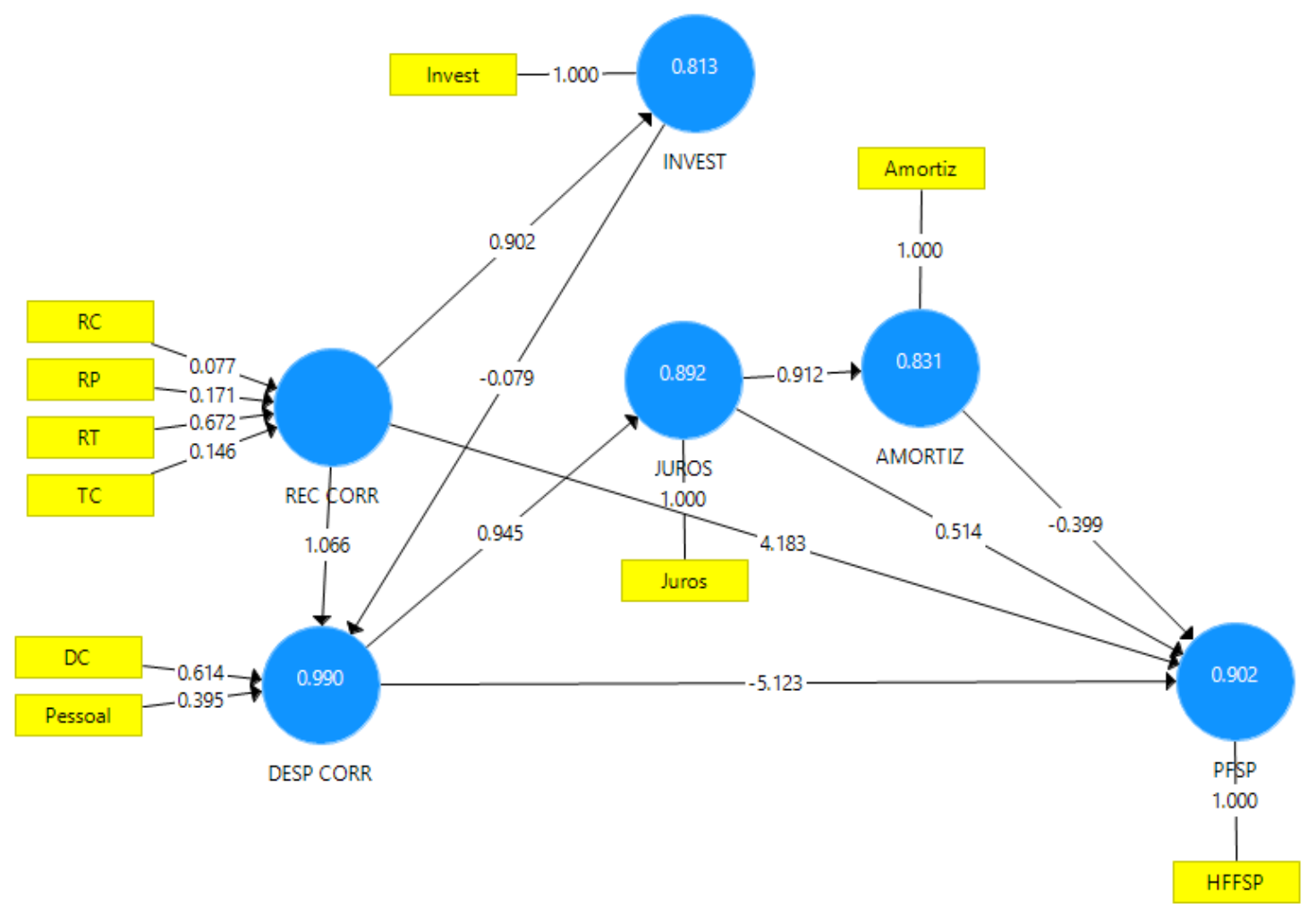

Source: The authors.

Figure 2. Structural Model

As SEM works with linear regression, when there is a correlation between two variables, the slope of the line indicates a positive effect. Therefore, when two variables are positive and 'increase together', the line slopes in the same way as when the line is negative and the two variables 'decrease together'. Another issue that contributes to the explanation and understanding of the positive effect of Interest on PSFP is the fact that in some states, there is a decrease or even stabilisation of total Interest spending, while Current Expenditure 
grows and Current Revenues decrease. Such phenomena may affect the SEM's simultaneous regressions as well as the statistical relationships.

Note that this evidence of a fall in recognition of interest and/or stabilisation does not mean that there was a decrease in this expenditure among the states. This effect may be due to non-determination of interest payable due to the lack of resources to meet it. Furthermore, such an exception may occur due to multicollinearity problems, the effects of which include inconsistent signs for correlations (De Souza Bido et al., 2010). Nevertheless, this effect can be minimised or even dismissed due to the validation procedures of the constructs presented in this study.

A distinguishing feature of SEM is that the model permits the use of variables that, while endogenous (dependent), are also exogenous (independent) and affect other constructs. Such is the case for the construct Interest. In this SEM application, as the dependent variable, Interest obtained a coefficient of 0.945 for effect on Current Expenditure and, as an independent variable, showed a coefficient of 0.912 on Amortisation. Despite the rejection of $\mathrm{H} 8$, with these qualifications, interest has been demonstrated to affect amortisations and therefore have a negative effect on the PSFP calculation.

\subsubsection{Convergent validity, collinearity and significance and relevance}

The instructions of Hair et al. (2014) state that when evaluating formative measurement models, convergent validity, collinearity and significance and relevance analyses are pertinent.

Convergent validity, also known as redundancy analysis, measures positive correlations among indicators of the same construct. This procedure is performed to test whether the construct is highly correlated with measures of the same construction (Hair et al., 2014). When performing validation procedures, constituting reflective models with a global variable that summarises the constructs, both in Current Revenues (Curr Rev - 1.0), and in Current Expenditure (Curr Exp - 0.983), the calculated $\mathrm{R}^{2}$ values are greater than 0.64 , and thus valid according to Hair et al. (2014, p. 121).

The following test is to verify multicollinearity, which according to Grewal and Baumgartner (2004), De Souza Bido et al. (2010) and Hair et al. (2014), when evidenced in formative measurement models, affects measurement of the effect and estimation of the weights and statistical significance of the indicators, which can also lead to problems with the interpretation of the relevance of these same indicators. Table 4 shows the multicollinearity statistic.

Table 4. Collinearity statistic (variance inflation factor - VIF)

\begin{tabular}{l|r}
\hline & \multicolumn{1}{|l}{ VIF } \\
\hline Amortisation & 1.000 \\
Current Expenditures & 14.118 \\
PSFP & 1.000 \\
Invest & 1.000 \\
Interest & 1.000 \\
Staff & 14.118 \\
Current Revenue & 9.882
\end{tabular}




\begin{tabular}{l|r} 
Financial Revenue & 2.488 \\
Tax Revenue & 12.032 \\
Current Transfer & 2.999 \\
\hline
\end{tabular}

Source: The authors.

Analysis of the indices shown in Table 4 reveals indices higher than those indicated in the literature for their validation, i.e., indices $\geq 5$ (Hair et al., 2014). According to Hair et al. (2014), high correlations among formative constructs can cause this type of problem, and methodological and model interpretation aspects should be considered. It should be noted that at first, the model was conducted with the variables and their values in the current and updated currency as described in the methodology. When the tests were performed, the problem of multicollinearity was evidenced. A variable standardisation procedure was performed along with changes in the formation of constructs and model, following the guidelines of De Souza Bido et al. (2010); however, the restriction still persisted.

In general, when there are multicollinearity problems in formative models, many of the actions are unsatisfactory (Grewal and Baumgartner, 2004), leaving the researcher with no other alternatives. De Souza Bido et al. (2010) and Hair et al. (2014) note that there is no theoretical reason to substitute the indicators in the formative models and that if these are estimated correctly, it is acceptable not to replace the constructs and to accept collinearity.

Also noteworthy are the considerations of De Souza Bido et al. (2010) that there will be loss in the interpretative power of each indicator but that this fact may not pose a difficulty, depending on the decision to be made on these results.

However, Grewal, Cote and Baumgartner (2004), analyzing multicollinearity, highlighted that estimation with high reliability, varying from 0.8 to 0.9 or higher, show accuracy and least likely errors Type II. Another condition that minimizes this kind of problems is the Average Variance Extracted - AVE, with index greater than 0.50, and square roots greater than the correlation indexes among constructs (Fornell and Larcker, 1981; Ringle, Da Silva and Bido, 2014). Thus Grewal, Cote and Baumgartner (2004) conclude that good measure reliability, explanatory power of the model and a large sample size, can minimize the problem of multicollinearity. These conditions are presented in this research.

The positive effect of Interest on PSFP, according to the structural model, could also be explained by endogeneity. The endogeneity can occur mainly due to some omitted variables in the model or simultaneous relationships that can lead to reverse causality among some of the constructs (Hair et al., 2019; Abdallah et al. 2015). In addition, these restrictions could cause correlation between the independents variables and the error term (Wooldridge 2013), and also coefficients estimations biased and inconsistent (Papies, Ebbes, and van Heerde 2017; Hult et al., 2018).

To assess whether the problem of endogeneity causes biased and inconsistent estimations, Hult et al. (2018) suggested the Gaussian Copula approach. This procedure controls endogeneity, modeling the correlation between the endogenous variable and the error term and assessing the significance of the copula coefficient using bootstrapping (Park \& Gupta, 2012). Synthesizing, if the copula coefficient is not significant, no critical endogeneity issue affects the regression results, thus, the original model's will not be biased and inconsistent (Park \& Gupta, 2012; Papies, Ebbes, and van Heerde 2017; Hult et al., 2018). 
In this way, following Hult et al. (2018), the procedures of the Gaussian Copula approach were carried out. First, the outputs of the latent variables obtained by Smart-PLS were exported to R Studio software and a linear regression with these variables was run, then the Kolmogorov - Smirnov test with Lilliefors was applied to assess whether the sample has a normal distribution, being rejected. In other step, were calculated copulas for independent variables within model. Then it was calculated the corrected $\mathrm{p}$-values for regression, based on bootstrapped standard errors. Finally, the significance analysis was put in place. The results are described in the Table 5 - Gaussian Copula (endogeneity assessment).

The new variables REC CORR_g, DESP CORR_g, INVEST_g, AMORTIZ_g and JUROS_g, are the copulas evaluated for independent variables within the model. The copulas p-values are willing in Table 5 - Gaussian Copula (endogeneity assessment). In the guidelines, presented by Hult et al. (2018), copulas are evaluated by simulations, running regressions for each copula separately and then combinatorial simulations between them. For this study, simulations were run, attaching two different copulas and a regression including all copulas. As it can be seen, all copulations have p-values above 0.10, except INVEST_g, which showed significance in a simulation (0.0595). It can be inferred that the endogeneity evidenced, among the latent variables of SEM, are not causing biased and inconsistent estimations and do not represent a potential problem (Park \& Gupta, 2012; Papies, Ebbes, and van Heerde 2017; Hult et al., 2018). 
$\underline{\text { Table } 5 \text { - Gaussian Copula (endogeneity assessment) }}$

\begin{tabular}{|c|c|c|c|c|c|c|c|c|c|c|c|c|}
\hline Variable & $\begin{array}{c}\text { Original } \\
\text { Model }\end{array}$ & $\begin{array}{c}\text { Gaussian } \\
\text { Cop. } 1\end{array}$ & $\begin{array}{c}\text { Gaussian } \\
\text { Cop. } 2\end{array}$ & $\begin{array}{c}\text { Gaussian } \\
\text { Cop. } 3\end{array}$ & $\begin{array}{c}\text { Gaussian } \\
\text { Cop. } 4\end{array}$ & $\begin{array}{c}\text { Gaussian } \\
\text { Cop. } 5\end{array}$ & $\begin{array}{c}\text { Gaussian } \\
\text { Cop. } 6\end{array}$ & $\begin{array}{c}\text { Gaussian } \\
\text { Cop. } 7\end{array}$ & $\begin{array}{c}\text { Gaussina } \\
\text { Cop. } 8\end{array}$ & $\begin{array}{c}\text { Gaussian } \\
\text { Cop. } 9\end{array}$ & \begin{tabular}{|c|} 
Gaussinan \\
Cop. 10
\end{tabular} & $\begin{array}{c}\text { Gaussian } \\
\text { Cop. } 11\end{array}$ \\
\hline \multirow[t]{2}{*}{ REC CORR } & 3,855 & 3,8182 & 3,8411 & 3,9008 & 3,70773 & 3,687 & 3,8879 & 3,7634 & 3,7661 & 3,901 & 3,937 & 3,9412 \\
\hline & 0,000 & 0,002 & 0,000 & 0,002 & 0,001 & 0,001 & 0,000 & 0,000 & 0,000 & 0,000 & 0,000 & 0,004 \\
\hline \multirow[t]{2}{*}{ DESP CORR } & $-4,863$ & $-4,9327$ & $-4,8622$ & $-4,9297$ & $-4,8249$ & $-4,8236$ & $-4,91$ & $-4,8955$ & $-4,9153$ & $-4,937$ & $-4,9701$ & $-5,0087$ \\
\hline & 0,0000 & 0,0000 & 0,0000 & 0,0000 & 0,0000 & 0,0000 & 0,0000 & 0,0000 & 0,0000 & 0,0000 & 0,0000 & 0,0000 \\
\hline \multirow[t]{2}{*}{ INVEST } & 0,2037 & 0,1913 & 0,2075 & 0,0525 & 0,2016 & 0,2062 & 0,0511 & 0,1918 & 0,198 & 0,0086 & 0,0126 & 0,0007 \\
\hline & 0,0068 & 0,2899 & 0,2168 & 0,8649 & 0,2115 & 0,2308 & 0,8627 & 0,2256 & 0,2253 & 0,9713 & 0,9570 & 0,9979 \\
\hline \multirow[t]{2}{*}{ JUROS } & 0,4168 & 0,5207 & 0,4342 & 0,5358 & 0,5138 & 0,5293 & 0,5347 & 0,5307 & 0,5487 & 0,5538 & 0,5711 & 0,5987 \\
\hline & 0,0004 & 0,0954 & 0,0704 & 0,097 & 0,1123 & 0,1158 & 0,0778 & 0,0789 & 0,0794 & 0,0308 & 0,0214 & 0,0777 \\
\hline \multirow[t]{2}{*}{ AMORTIZ } & 0,4249 & $-0,4612$ & $-0,4512$ & $-0,4567$ & $-0,4576$ & $-0,4547$ & $-0,456$ & $-0,4524$ & $-0,4582$ & $-0,4167$ & $-0,4398$ & $-0,4218$ \\
\hline & 0,0000 & 0,0008 & 0,0077 & 0,0007 & 0,0086 & 0,0007 & 0,0004 & 0,0066 & 0,0007 & 0,0036 & 0,0001 & 0,0092 \\
\hline \multirow[t]{2}{*}{$\begin{array}{l}\text { REC } \\
\text { CORR_g }\end{array}$} & & $-0,0387$ & & $-0,0131$ & 0,0565 & 0,0727 & & & & & & $-0,0234$ \\
\hline & & 0,8776 & & 0,9288 & 0,5982 & 0,5892 & & & & & & 0,9317 \\
\hline \multirow{2}{*}{$\begin{array}{l}\text { DESP } \\
\text { CORR_g }\end{array}$} & & & & & & & & & & & & \\
\hline & & 0,0968 & & & & & $-0,015$ & 0,0706 & 0,0853 & & & $\begin{array}{l}0,0521 \\
07839\end{array}$ \\
\hline \multirow[t]{2}{*}{ INVEST_g } & & 0,6115 & & 0,1099 & & & $\begin{array}{r}0,9089 \\
0,112\end{array}$ & 0,4649 & 0,4560 & 0,1363 & 0,1493 & $\begin{array}{l}0,7839 \\
0,1489\end{array}$ \\
\hline & & & & 0,3801 & & & 0,3871 & & & 0,1072 & 0,0595 & 0,2002 \\
\hline \multirow[t]{2}{*}{ JUROS_g } & & & $-0,0020$ & & & $-0,0208$ & & & $-0,0299$ & & $-0,0619$ & $-0,0597$ \\
\hline & & & 0,9755 & & & 0,8140 & & & 0,7310 & & 0,2395 & 0,4887 \\
\hline \multirow[t]{2}{*}{ AMORTIZ_g } & & & 0,0234 & & $-0,0005$ & & & $-0,0132$ & & 0,0487 & & $-0,0332$ \\
\hline & & & 0,7267 & & 0,9940 & & & 0,8635 & & 0,4112 & & 0,6525 \\
\hline
\end{tabular}


Continuing with the model validation procedures, the significance and relevance of the formative indicators were then analyzed. As indicated in the descriptive statistical analysis, the PLS-SEM method can be applied to non-parametric samples, as it is indifferent to nonnormal distributions. However, the bootstrapping procedure is used to test significant relationships. In this procedure, a large number of the population sub-samples are taken randomly and again used in a resampling procedure. Relations with a p-value of $\leq 0.05$ are considered significant (Hair et al., 2014).

Table 6. Bootstrapping (External loadings)

\begin{tabular}{l|r|r|r|r|r}
\hline & $\begin{array}{c}\text { Original } \\
\text { sample (O) }\end{array}$ & $\begin{array}{c}\text { Sample } \\
\text { mean (M) }\end{array}$ & $\begin{array}{c}\text { Standard } \\
\text { deviation } \\
\text { (STDEV) }\end{array}$ & $\begin{array}{c}\text { T Statistic } \\
(\mid \mathbf{O} / \text { STDEV })\end{array}$ & p-value \\
\hline Amortis <- AMORTIS & 1.000 & 1.000 & 0.000 & & \\
CE -> CURR EXP & 0.994 & 0.994 & 0.003 & 286.307 & 0.000 \\
PSFP <- PSFP & 1.000 & 1.000 & 0.000 & & \\
Invest -> INVEST & 1.000 & 1.000 & 0.000 & & \\
Interest <- INTEREST & 1.000 & 1.000 & 0.000 & & \\
Staff -> CURR EXP & 0.987 & 0.984 & 0.013 & 78.494 & 0.000 \\
CR -> CURR REV & 0.953 & 0.948 & 0.026 & 36.283 & 0.000 \\
FR -> CURR REV & 0.810 & 0.820 & 0.053 & 15.409 & 0.000 \\
TR -> CURR REV & 0.991 & 0.988 & 0.007 & 142.255 & 0.000 \\
CT -> CURR REV & 0.838 & 0.834 & 0.044 & 19.147 & 0.000 \\
\hline
\end{tabular}

Source: The authors.

According to the bootstrapping test performed and shown in Table 6, all relationships were considered significant, and therefore, the significance and importance of these indicators were statistically verified. Moreover, for external loadings with values above 0.50 , the indicator is maintained (Hair et al., 2014).

Although the analysis of predictive relevance of the endogenous constructs in the formative models is not shown, we took the liberty of performing and presenting this test, given the relevance of confirming the Interest and Amortisation variables in the PSFP's calculation, as pointed out in the theoretical framework and research problem. The blindfolding procedure was used for this purpose.

Table 7. Blindfolding

\begin{tabular}{l|r|r|rr}
\hline & \multicolumn{1}{|c|}{ SSO } & \multicolumn{1}{c|}{ SSE } & \multicolumn{2}{c}{$\mathbf{Q}^{2}$} \\
& & & \multicolumn{1}{c}{ (=1-SSE/SSO $)$} \\
\hline AMORTIS & 135.000 & 26.424 & & 0.804 \\
CURR EXP & 270.000 & $\mathrm{n} / \mathrm{d}$ & $\mathrm{n} / \mathrm{d}$ & \\
INVEST & 135.000 & 31.251 & & 0.769 \\
INTEREST & 135.000 & 18.257 & & 0.865 \\
PSFP & 135.000 & 24.868 & & 0.816
\end{tabular}




\begin{tabular}{l|l|l|l} 
CURR REV & 540.000 & 540.000 & \\
\hline
\end{tabular}

Source: The authors.

Table 7 shows the results of the blindfolding procedure. SSO represents Sum of Squares of Observations and SSE, Sum of Squares of Errors. According to Hair et al. (2014), values in the range of 0.02 have low predictive ability, whereas values above 0.35 have a high predictive ability. Thus, the endogenous constructs Amortisation, Interest and PSFP had a high predictive ability, supporting the theoretical assumptions presented in this article.

Such evidence confirms the effects and relevance of the Interest and Amortisation variables in determining the PSFP. According to the considerations of Taylor and O'Connell (1985); Minsky (1992); De Paula and Alves Jr. (2000); Foley (2003); Ferrari-Filho, Terra and Conceição (2010); Terra and Ferrari Filho (2011, 2017) and Picolotto (2016), financial fragility is formed not only as a function of an excess in current spending but also due to Interest and Amortisation spending that exceeds the balance calculated between Current Revenue and Current Expenditure. The deficiency in resources that generates financial fragility can be linked to insufficient resources, spending above revenue collection capacity or even to excessive interest that affects the distribution of the application of public resources.

While Musgrave's (1973) contributions explain the necessity and relevance of public debt as a fiscal policy tool, Minsky $(1977,1985,1992)$ describes distinct motives for the generation of economic agents' debt, the foundation of the FFH. However, in both cases, there is an effect of interest and amortisation on the finances of both economic agents and governments. In addition to the descriptions of the effects of interest on financial position, presented throughout this study, other research can be cited, such as that of Triches and Bertussi (2017), who investigated Brazilian fiscal sustainability in the 1997-2015 period and the effects on public spending and public debt. The authors concluded that the nominal deficit showed high growth, mainly due to the nominal interest and debt service. Such evidence demonstrates poor sustainability of fiscal policy, which is affected by interest and debt amortisation.

In short, considering the structural model and the hypotheses tested and having corroborated their validity with the tests conducted, it can be demonstrated that such constructs showed effects on the Debt Service, as well as on the PSFP, supporting the theoretical bases of the FFH as applied to the public sector. This support is shown by the impact of interest, both in determining the amortisation portion according to an $\mathrm{R}^{2}$ of 0.831 and in the predictor calculated as 0.912 as well as for the PSFP. This evidence confirms the assumptions of the effect of these variables in the calculation of the hedge, speculative and Ponzi financial positions.

\section{Final considerations}

This study analysed the effects of public debt interest and charges on the financial position of Brazilian states. To that end, the fundamentals of the FFH applied to the public sector were tested. SEM was used as the empirical procedure for analysis and testing.

The theoretical considerations underlying this work gave rise to a study of the effect of public debt interest and charges on Brazilian states' financial positions, based on the model presented by Ferrari-Filho, Terra and Conceição (2010) and Terra and Ferrari Filho (2011, 
2017, 2020). In the analysis of the effects of the structural model constructs as shown in Figure 2, in general, all the latent variables chosen explained 90.2\% of the Public Sector Financial Position-specifically, for this study, the Brazilian states' financial position. This evidence, supported by the convergent validity, significance and relevance and predictive ability tests, reinforces the relevance of the use of SEM for the evaluation of the FFH applied to the public sector and its relationship with the constructs Current Revenues, Current Expenditure, Investments, Interest and Amortisation.

Although there was multicollinearity in the model, this problem was disregarded according to the guidelines and cautions of both De Souza Bido et al. (2010) and Hair et al. (2014). According to these authors, depending on the model, the removal of some indicators to reduce or extinguish the problem of multicollinearity may, contrary to the intention, compromise the analysis, because according to the theoretical basis for the formation of hypotheses and specification of indicators, any exclusion can affect the model's explanatory power. In this regard, in this study, such exclusions could have caused more restrictions than the problems they were intended to address.

In addition, the inclusion procedures of Gaussian Copulas were carried out in order to treat endogeneity problems, which could be related to the evidenced multicollinearity. The procedures performed validated the model, excluding the likelihood of the estimates being biased and inconsistent.

Furthermore, other tests reinforced the validity and significance of the model. Despite the restrictions resulting from multicollinearity, the analysed associations among the indicators and constructs were validated using the bootstrapping procedure.

When analysing the research problem, that is, to determine the effects of public debt interest and charges on Brazilian states' financial positions, the convergent validity, significance and relevance and predictive ability tests supported the relevance of the results and indicated that the Interest and Amortisation constructs had significance and validity. Among the aspects that deserve further analysis is the positive effect of Interest on the Amortisation variable, corroborated by the predictor value of 0.912 and the negative effect of Amortisation on PSFP, with a predictor of -0.399. These findings reinforce Foley's observations (2003) in regard to the causes of financial fragility and its relation to interest rates, fiscal austerity policies and economic activity. The warnings raised by Taylor and O'Connell (1985), Foley (2003) and De Paula and Alves Jr. (2000) indicate the significance of interest in affecting, or even determining, financial fragility. Interest will affect both the debt service value and the cash flows needed for the maintenance of production activity.

Current Expenditure has a predictor of -5.123. These data corroborate the explanation of the significance of Interest and Amortisation on the states' financial positions and the predominance of spending with current expenditure, with staff spending - 0.395 - being relevant both in costing and affecting Financial Position. However, the Interest construct had a positive effect on PSFP. This effect may be because the PSFPs for this sample and in this period of time had negative results in many observations. Thus, a negative effect on a negative result has a positive effect, since a negative variable added to an equally negative position increases the negative result. This characteristic may explain the positive effect. Decreased recognition of interest in the budget in terms of possible non-fulfilment of commitment, plus its relationship with the variations in Current Revenue and Current Expenditure, may also have contributed to such a restriction. Moreover, this effect may have been due to the multicollinearity problems, which were disregarded based on the empirical and theoretical foundations presented by De Souza Bido et al. (2010) and Hair et al. (2014). 
Note that according to the blindfolding procedure, the endogenous constructs Amortisation and Interest had a high predictive ability, supporting the theoretical assumptions presented in this article. Such findings corroborate the effects and relevance of the Interest and Amortisation variables in determining the PSFP. In line with the considerations of Taylor and O'Connell (1985), Minsky (1992), De Paula and Alves Jr. (2000), Foley (2003), FerrariFilho, Terra and Conceição (2010), Terra and Ferrari Filho (2011, 2017, 2020) and Picolotto (2016), financial fragility is formed not only as a function of an excess in current spending but also due to Interest and spending with Amortisation that exceed the balance calculated in the comparison between Current Revenue and Current Expenditure.

According to Minsky's reflections, excessive interest in the cost of debt leads to complications at the fiscal debt level and determination of the government spending level, when analysed on a macroeconomic basis (Taylor and O'Connell, 1985). This deficiency of resources generating financial fragility can be linked to insufficient resources, expenditure above revenue collection capacity or even excessive interest that affects the distribution of the application of public resources.

These empirical procedures and data analysis led to the structural model and the tested hypotheses being corroborated according to the tests performed. Such constructs showed effects on the Debt Service, as well as on the PSFP, supporting the theoretical bases of the FFH as applied to the public sector. This evidence confirms the assumptions of the effect of the Interest and Amortisation variables on the calculation of hedge, speculative and Ponzi financial positions when applied to the public sector.

The limitations of this study include the multicollinearity problem, the sample size and high data dispersion, despite the attempt to minimise this effect via standardisation. As a suggestion for future research using SEM to explain the effect of variables in problems related to financial fragility or even public finance issues, perhaps single-item structural equation models can eradicate the problem of multicollinearity and eliminate restrictions to the estimation of weights and/or problems with the interpretation of relevance of indicators. However, such models have the disadvantage of presenting constructs with a poor variety of indicators, which affects the characteristics of structural equations in their plurality and in their ability to bring together various indicators to form a construct.

\section{References}

Abdallah, W., Goergen, M., and O’Sullivan, N. 2015. "Endogeneity: How Failure to Correct for it Can Cause Wrong Inferences and Some Remedies," British Journal of Management (26:4), pp. 791-804.

Anderson, J. C., \& Gerbing, D. W. (1988). Structural equation modeling in practice: A review and recommended two-step approach. Psychological bulletin, 103(3), 411.

Argitis, G., \& Nikolaidi, M. (2016). Debt crisis, fiscal austerity and the financial fragility and instability in the Greek economy.

Barro, R., 1979. On the determination of the public debt. Journal of Political Economy 87 (5), 940-71

De Paula, L. F. R., \& Alves Jr, A. J. (2000). External financial fragility and the 1998-1999 Brazilian currency crisis. Journal of Post Keynesian Economics, 22(4), 589-617. 
de Souza Bido, D., da Silva, D., de Souza, C. A., \& Godoy, A. S. (2010). Mensuração com indicadores formativos nas pesquisas em administração de empresas: como lidar com a multicolinearidade entre eles?. Administração: Ensino e Pesquisa, 11(2), 245-269.

Faul, F., Erdfelder, E., Lang, A.-G. \& Buchner, A. (2007). G*Power 3: A flexible statistical power analysis program for the social, behavioral, and biomedical sciences. Behavior Research Methods, 39, 175-191.

Ferrari-Filho, F; Terra, F.H.B.; Conceição, O.A.C. (2010). The financial fragility hypothesis applied to the public sector: an analysis for Brazil's economy from 2000 to 2008. Journal of Post Keynesian Economics, vol. 33, n. 1, 151-168..

Foley, D. (2003). Financial fragility in developing economies. DUTT, Amitava K.; ROSS, Jaime. Development economics and structuralist macroeconomics. Cheltenham: Edward Elgar, 157-168.

Fornell, C.; Larcker, D.F. Evaluating structural equation models with unobservable variables and measurement error. Journal of Marketing Research. v.18, n. 1, p. 39-50, 1981.

González A. H. (2017). Economia e Sociedade, Campinas, v. 26, Número Especial, p. 9911023.

Grewal, R., Cote, J. A., \& Baumgartner, H. (2004). Multicollinearity and measurement error in structural equation models: Implications for theory testing. Marketing science, 23(4), 519529.

Hair, J. F. Jr.; Anderson, R. E.; Tathan, R. L.; Black, W. C; (2005). Análise Multivariada de dados. ed. Porto Alegre: Bookman,.

Hair, J. F., Hult, G. T. M., Ringle, C., \& Sarstedt, M. (2014). A primer on partial least squares structural equation modeling (PLSSEM). Sage Publications

Hair, J. F., Risher, J. J., Sarstedt, M., \& Ringle, C. M. (2019). When to use and how to report the results of PLS-SEM. European Business Review.

Henseler, J.; Ringle, C. M.; Sinkovics, R. R. (2009). The use of partial least squares path modeling in international marketing. Advances in International Marketing. v. 20, p. 277-319.

Hult, G. T. M., Hair Jr, J. F., Proksch, D., Sarstedt, M., Pinkwart, A., \& Ringle, C. M. (2018). Addressing endogeneity in international marketing applications of partial least squares structural equation modeling. Journal of International Marketing, 26(3), 1-21.

Keynes, J. M. (1996). A Teoria Geral do Juro do Emprego e da Moeda. São Paulo: Nova Cultural.

Minsky, H. P. (1977). The financial instability hypothesis: An interpretation of Keynes and an alternative to "standard" theory. Challenge, 20(1), 20-27.

Minsky, H. P. (1985). The legacy of Keynes. The Journal of Economic Education, 16(1), 515 .

Minsky, H P. (1986). Stabilizing an Unstable Economy. Twentieth Century Fund Report: New Heaven.

Minsky, H P. (1992). The Financial Instability Hypothesis. The Jerome Levy Economics Institute Working Paper No. 74. May.

Musgrave, R. A. (1973) Teoria das finanças públicas: um estudo de economia

Governamental. Atlas: São Paulo. 
Papies, Dominik, Peter Ebbes, and Harald J. van Heerde (2017),“Addressing Endogeneity in Marketing Models," in Advanced Methods for Modeling Markets, P.S.H. Leeflang, J.E. Wieringa, T.H.A. Bijmolt, and K.H. Pauwels, eds. New York: Springer, 581-627.

Park, Sungho, and Sachin Gupta (2012), "Handling Endogenous Regressors by Joint Estimation Using Copulas," Marketing

Science, 31 (4), 567-86.

Picolotto, V. D. C. (2016). Política fiscal e endividamento público em um contexto de estado subnacional: uma perspectiva pós-keynesiana para o Rio Grande do Sul no período 19952014.

Ringle, C. M., Da Silva, D., \& Bido, D. D. S. (2014). Modelagem de equações estruturais com utilização do SmartPLS. Revista Brasileira de Marketing, 13(2), 56-73.

Taylor, L., \& O'Connell, S. A. (1985). A Minsky crisis. The Quarterly Journal of Economics, 100(Supplement), 871-885.

Terra, F. H. B \& Ferrari Filho, F. (2011). A hipótese de fragilidade financeira aplicada ao setor público: uma análise para a economia brasileira no período de 2000-2009, Revista Economia, v. 12, n. 3, p. 497-516.

Terra, F. H. B., \& Ferrari Filho F. (2017) Índice de Fragilidade Financeira do Setor Público revisitado: uma análise para o governo federal brasileiro no período 2000-2016. Anais do XII Congresso Brasileiro de História Econômica \& $13^{\text {a }}$ Conferência Internacional de História de Empresas.terr

Terra, F. H. B., \& Ferrari Filho, F. (2020). Public Sector Financial Fragility Index: an analysis of the Brazilian federal government from 2000 to 2016. Journal of Post Keynesian

Economics, 1-25.

Triches Divanildo, B. L. A. S. (2017). Multicointegração e Sustentabilidade da Política Fiscal no Brasil com Regime de Quebras Estruturais (1997-2015). Revista Brasileira de Economia, 71, 379-394.

Wooldridge, Jeffrey M. (2013), Introductory Econometrics. A Modern Approach, 5th ed. Mason, OH: South Western, Cengage Learning. 